\title{
Food Insecurity and its Determinants among Farming Households in Surulere Local Government Area of Oyo State
}

\author{
Adio Matthew Olufemi ${ }^{1 *}$, Oladele, Adeniyi Bamidele ${ }^{2}$ \\ ${ }^{\mathrm{T}}$ Department of Agricultural Economics and Extension, Faculty of Agriculture, Federal University, Oye-Ekiti, Ekiti State, \\ Nigeria \\ ${ }^{2}$ Department of Agricultural Economics, Faculty of Agriculture, Ladoke Akintola University of Technology, Ogbomoso, \\ Oyo State, Nigeria
}

\section{*Corresponding Author}

Adio Matthew Olufemi

\section{Article History}

Received: 02.03.2021

Accepted: 19.03 .2021

Published: 26.03.2021

\begin{abstract}
The study examined the determinants of household food insecurity in Surulere Local Government Area of Oyo State. Multistage random sample technique was used in the selection of the respondents. The result the mean age of the respondents was 50.91 years and that $94.17 \%$ were married with an average household size of 9 persons. Also, the respondents had an average of 30.21 farming experience and majority of the farmers in the study area were educated enough to enable them successfully adopt innovations to improve their productivity incomes and welfare. The mean farm size in the study area was 3.53 hectares. The results of the food security status revealed that majority (58.33\%) of the respondents described their food security status to be secured while others $(41.67 \%)$ were of the view that their food security status was not secured. The result of binary Probit regression analysis also indicated that age, sex and education had a significant effects on food security at $\mathrm{p}<0.05$ respectively. This study therefore concluded that since education is significant, farmers will be able to gain adequate knowledge on understanding the best ways of alleviating the problems of food security.
\end{abstract}

Keywords: Food Insecurity, Determinants, Farming household, Probit Regression.

\section{INTRODUCTION}

Household food insecurity is increasingly known to be a global health problem, especially in Sub-Saharan Africa. The Sustainable Development Goals (SDGs) have emphasised the urgent need to tackle food insecurity in achieving human rights by the year 2030.The first goal is to end 'poverty in all its forms everywhere', and the second is to 'end hunger, achieve food security, improved nutrition, and promote sustainable agriculture'; both goals have been clearly stated as the frontline of the SDGs, Drammeh, Hamid, and Rohana [1].

Food security is widely seen as access of all people at all times to enough food for an active life, while food insecurity is the inability of a household or individuals to meet the required consumption levels in the face of fluctuating production, price and income [2]. A household is said to be food secure if it can reliably gain access to food in sufficient quantity and quality for household members to enjoy a healthy and active life [3]. Rural food insecurity is one of the defining features of rural poverty, Agidew, and Singh [4]. They went further to add that food is not only a basic need, it also provides the physiological foundation upon which other considerations and human activities are structured. In Nigeria, food security is both a national objective and a challenge. The subject of food insecurity has attracted attention the world over, given its direct link to malnutrition which leads to poor physical and mental health. According to Drammeh, Hamid, and Rohana [1], food insecurity is linked to acute and chronic physical and mental health conditions such as higher levels of stress, anxiety, irritability, social isolation, heightened emotional responsiveness, eating disorders, depression as well as impaired cognitive abilities.

Copyright $(92021$ The Author(s): This is an open-access article distributed under the terms of the Creative Commons Attribution 4.0 International License (CC BY-NC 4.0) which permits unrestricted use, distribution, and reproduction in any medium for noncommercial use provided the original author and source are credited. 
Food security defined as access by all people at all times to enough food for an active and healthy life, is one of the major factors necessary for a household members, particularly children, to be healthy and well-nourished [5]. Food insecurity, in turn, refers to limited or uncertain physical and economic access to secure sufficient quantities of nutritionally adequate and safe foods in socially acceptable ways to allow household members to sustain active and healthy living $[6,7]$. By this definition, household food insecurity has two broad components: insufficient access to a nutritionally adequate and safe food supply at the household level [7, 8], and inadequate utilization of these foods by household members. Household food insecurity can negatively affect food consumption, including reduced dietary variety, nutrient intake, and nutritional status of household members.

Food security ranks the top most among development problems facing Nigeria. The level of food insecurity has continued to rise steadily since the 1986 to about $41 \%$ in 2004 [9]. According to Barrett [3], the lack of food excludes people to practice what other people are doing every time. However, large amount of food production in the world does not ensure any country's food security. Moreover, huge production of food at national level does not guarantee for the household food security. This may be due to unfair distribution of resources, variation in production functions, and motives for productivity. That is why even if the production increases through time; food insecurity, malnutrition and hunger remain the main agenda and much more serious problems in the world today.

Despite much effort by the government of Nigeria to boost food production, food insecurity remains the main problem in our country and the need for food importation become increasing. The government needs to look for a way to reduce this situation. This is because Nigeria is still characterized by high reliance on food imports. Malnutrition is widespread in the entire country and rural areas are especially vulnerable to chronic food shortages, malnutrition, unbalanced nutrition, erratic food supply, poor quality foods, high food costs and even total lack of food. This phenomenon cuts across all age groups and categories of individuals in the rural areas [10]. There is a high level of malnutrition among children in rural Nigeria; the figures differ with geopolitical zones, with 56 percent reported in a rural area of South West and 84.3 percent in three rural communities in the northern part of Nigeria [11, 12].

Furthermore, the available historical series show that, about 852 million people world-wide were chronically undernourished between 1980-2005. About 800 million of this people live in developing countries [13]. Most of the studies that have been done so far on the issues of food security are very general and consider the problem from national, regional, and district points of view, Agidew, and Singh [4]. While aggregate data are generally available at the national level, little work has been done to understand the food security problems at the household level. Having national food balance data is not sufficient to understand determinants of food insecurity in rural farm households in the country. Most agricultural production comes from millions of rural households. Despite the increasing global concern of improving food security, the nature and extent of food security at the household level in rural areas are not well documented.

Moreover, available statistics show that at least 41 percent of the Nigerian populations are food insecure with $16 \%$ being severely undernourished [10]. The incidence of household food insecurity in Nigeria rose from 18 percent in 1986 to over 40 percent in 2005 [9]. It is essential therefore, to have the analysis of food insecurity done in the household level to understand the actual demand for food and thus its effect on the food security situation on households. This will be of immense help to understand the different household characteristics that are specific to food security and their implication on the food related issues. This study therefore, examined the determinant of household food insecurity in the study area.

\section{Methodology}

The study was conducted in Surulere Local Government Area in Ogbomoso Agricultural Zone of Oyo State. This Local Government area comprises of different villages which are rural in nature. The village is located approximately on the intersection of latitude $8^{\circ} 08^{\mathrm{i}}$ North and longitude $4^{\mathrm{o}} 15^{\mathrm{i}}$ East. It is about $105 \mathrm{~km}$ North East of Ibadan (state capital), 58km North West of Oyo town. The population was approximately 166,034 as of 2006 census, an area of $23 \mathrm{~km}^{2}$ with about $30 \%$ civil servant who as well engaged in farming, and the other $60 \%$ are into full time farming (both crops and animal production). Primary data was used for the study area. Data were collected with the use of wellstructured questionnaire which was developed based on the objectives of the study to collect information from the selected respondents through one on one interview approach.

Multistage random sample technique was used in the selection of the respondents. The first stage involved the purposive selection of Surulere Local Government. This is necessitated because of the rurality of the local government area. The second stage involved random selection of 5 wards out of the 10 wards in the local government. The third stage involved random selection of 2 villages from each wards selected making a total of 10 villages. The last stage involved random and proportional selection of 12 respondents from each village making a total of 120 respondents. 


\section{Anal YTiCAL FrameWORK}

The household food security can be modeled in the framework of consumer demand and production analysis following the Agricultural Household Models (AHMs) [4]. In AHM models an agricultural household is both a consumer and a producer. Given the assumption of "separability" of consumption variables and production variables, the AHM model household can separate production decisions from the consumption preferences-first it solves the production decisions (independent of consumption preferences) and then it solves the consumption decisions (based on optimal production decisions). The household utility function is specified as

$$
U=U\left(F_{i}, F_{m}, I: D_{h}\right)
$$

Where $U$ is a utility function that is assumed to be well behaved (twice differentiable, increasing in its arguments and strictly quasi-concave); $F_{i}$ is a vector of home-produced goods consumed by the household; $F_{m}$ is a vector of market purchased goods consumed by the household; and 1 is leisure. Here $D_{h}$ is the demographic characteristics of the household.

The household, as both producer and consumer, is assumed to maximize its utility from the consumption of the goods subject to farm production, income and time constraint such as

$$
\begin{gathered}
G\left(F Q_{i}, L, A^{o}, K^{o}\right)=0 \\
P_{i},\left(P Q_{i}-F_{i}\right)-P_{m} P_{m}-W\left(L-L_{f}\right)+N=0 \\
T=L_{f}+1
\end{gathered}
$$

where G(.) is an implicit production function that is assumed to be well-behaved(twice differentiable, increasing in outputs, decreasing in inputs and strictly convex); $\mathrm{Q}_{\mathrm{i}}$ is a vector of quantities of goods produced on-farm; $\mathrm{L}$ is total labour input to the farm; A0 is the household's fixed quantity of land; K0 is the fixed stock of capital; Pi is the price of good i; Pm is the price of market-purchased good; (Qi-Fi) is the marketed surplus of good i; w is the wage rate; Lf is the household labor supply for on-farm use; $\mathrm{N}$ is non-farm income that adjusts to ensure that equation(3) is zero; $\mathrm{T}$ is the total time available to the household to allocate between work and leisure.

Given the assumption of "separability," the production side can be solved first. The first-order conditions for input demand $\left(\mathrm{L}^{*}\right)$ and output supply $\left(\mathrm{Q}^{*}\right)$ in terms of all prices, wage rate, fixed land and capital as,

$$
\begin{aligned}
L^{*} & =L^{*}\left(P_{i}, W, A^{o}, K^{o}\right) \\
Q^{*} & =Q^{*}\left(P_{i}, W, A^{o}, K^{o}\right)
\end{aligned}
$$

And Rearranging equations (3) and (4) and putting $\mathrm{L}^{*}$ and $\mathrm{Q}^{*}$ into the rearranged equation,

$$
Y^{*}=P_{i} Q_{i}^{*}+W T-W L^{*}+N
$$

And

$$
Y^{*}=W T+\pi^{*}\left(P_{i}, W \cdot A^{o}, K^{o}\right)+N
$$

Where $\mathrm{Y}^{*}$ is "full" income under the assumption of maximized profit $\pi^{*}$.Now, the first-order conditions for consumption demand can be solved for in terms of prices, wage rate and income as-

$$
F_{k}=F_{k}\left(P_{i}, P_{m}, W, Y^{*}\right)
$$

(Here $\mathrm{k}=\mathrm{i}, \mathrm{m})$. Incorporating the household characteristics (Di), the demand for food can be rewritten as,

$$
F_{k,}=F_{k,}\left[P_{i,} P_{m}, W, Y^{*}\left(W, A^{o}, K^{o}, N\right), D_{h}\right]
$$

For the purpose of this study, food security index will be use to analyze household food security status. In food security index, food security line will be estimated from household monthly expenditure on food items. Any household spending above $2 / 3$ of food security line will be classified as food insecure while those below the $2 / 3$ of food security line will be classified as food secure. 
The food security index is given as:

$$
F_{i}=\frac{\text { per capita food expenditure for the ith households }}{2 / 3 \text { mean per capita food expenditure in all households }}
$$

Where

$$
F_{i}=\text { Food security index }
$$

When $F_{i} \geq 1=$ food secure ith household

$$
F_{i} \leq 1=\text { food insecure ith household }
$$

A food secure household is therefore that whose per capita monthly food expenditure falls above or is equal to two-third of the mean per capita food expenditure. On the other hand, a food insecure household is that whose per capita food expenditure falls below two-third of the mean monthly per capita food expenditure study area.

Probit Regression Model was used to analyse the determinant factors of household food security status in the

$$
\begin{aligned}
& P(Y=1)=F(X B)=\frac{1}{\sqrt{2 \pi}} \int_{-\infty}^{X B} e \frac{-(X B)^{2}}{2} d x \\
& X=\left(1, x_{1 i_{z}} x_{2 i_{z-m}=} x_{k i_{i}}\right) \\
& \beta^{\prime}=\beta_{o,} \beta_{1_{\text {gmam ma }}} \beta_{k_{p}}
\end{aligned}
$$

The dependent variable is: Food security Status (secured $=1$ and insecure $=0$ )

And the independent variables are:

$Y i=$ Dependent variable

$X i=$ Vector of explanatory variables

$\beta=$ Vector of respective parameters

$\ell=$ Independently distributed error term

Thus, the explanatory variables in the regression analysis were and measured as;

$\mathrm{X}_{1}=$ Age (in years)

$\mathrm{X}_{2}=$ Marital status (Married $=1$, Single, Divorced or Widowed $=0$ )

$\mathrm{X}_{3}=$ Gender $($ Female $=1$, Male $=0)$

$\mathrm{X}_{4}=$ Education

$\mathrm{X} 5$ = Household size

$\mathrm{X}_{5}=$ Extension Visit

$\mathrm{X}_{6}=$ Family Labour

$\mathrm{X}_{4}=$ Hired Labour

\section{RESULTS AND DISCUSSION}

\section{Socioeconomic Characteristics of the Respondents}

The result in Table 1 showed that $9.17 \%$ of the respondents were in the age range of $20-40$ years, $85.00 \%$ were in the age bracket of 41-60years, the mean age of the respondents in the study area was 50.91 years, which was in agreement with some studies $[15,16]$. About $56.67 \%$ of the respondents were male while $43.33 \%$ of them were female. This was an indication that male farmers are more involved in farming business than female counterparts which could be attributed to the energy/effort required for efficient management practices. This result disagrees with the work of Matsane and Oyekale [17] where 59.6\% of the respondents were female, and agrees with the work of Oladiran et al., [18] where $82.9 \%$ of the respondents were male. The result on of the marital status revealed that shows that $1.67 \%$ of the respondents were single, $94.17 \%$ were married and $4.17 \%$ of them were divorced. This implication of this is that most of the respondents in the study area were married. This will give them additional opportunity of having some assistance in their farming business. A large family size is important in the supply of farm labor in farming communities especially in Nigeria where farmers depend on human manual labour. Although, in a situation where the members of a family are 
mainly young children of school age and old family members, a large family size may not contribute much to farm production because they may be unable to contribute the much needed labour for farm operations. This study indicated that the mean household size of the respondents in the study area was 9 persons and this study corroborates with the work of Global Hunger [19] where the average family size was 6.2 and Oladiran et al., [18] where the mean household size was 6. The mean farming experience of the respondents was 30.21 years and this is in support of the work of Onyekuru [5]. Finally, analysis of the educational levels of respondents in the study area showed that $41.67 \%$ of the farmers had primary education, $44.17 \%$ had secondary education while $14.17 \%$ had tertiary education. Thus one can also conclude that majority of the farmers in the study area were educated enough to enable them successfully adopt innovations to improve their productivity incomes and welfare. This corroborates with the findings of Rios et al. [20] where majority of respondents had primary and secondary education in their community.

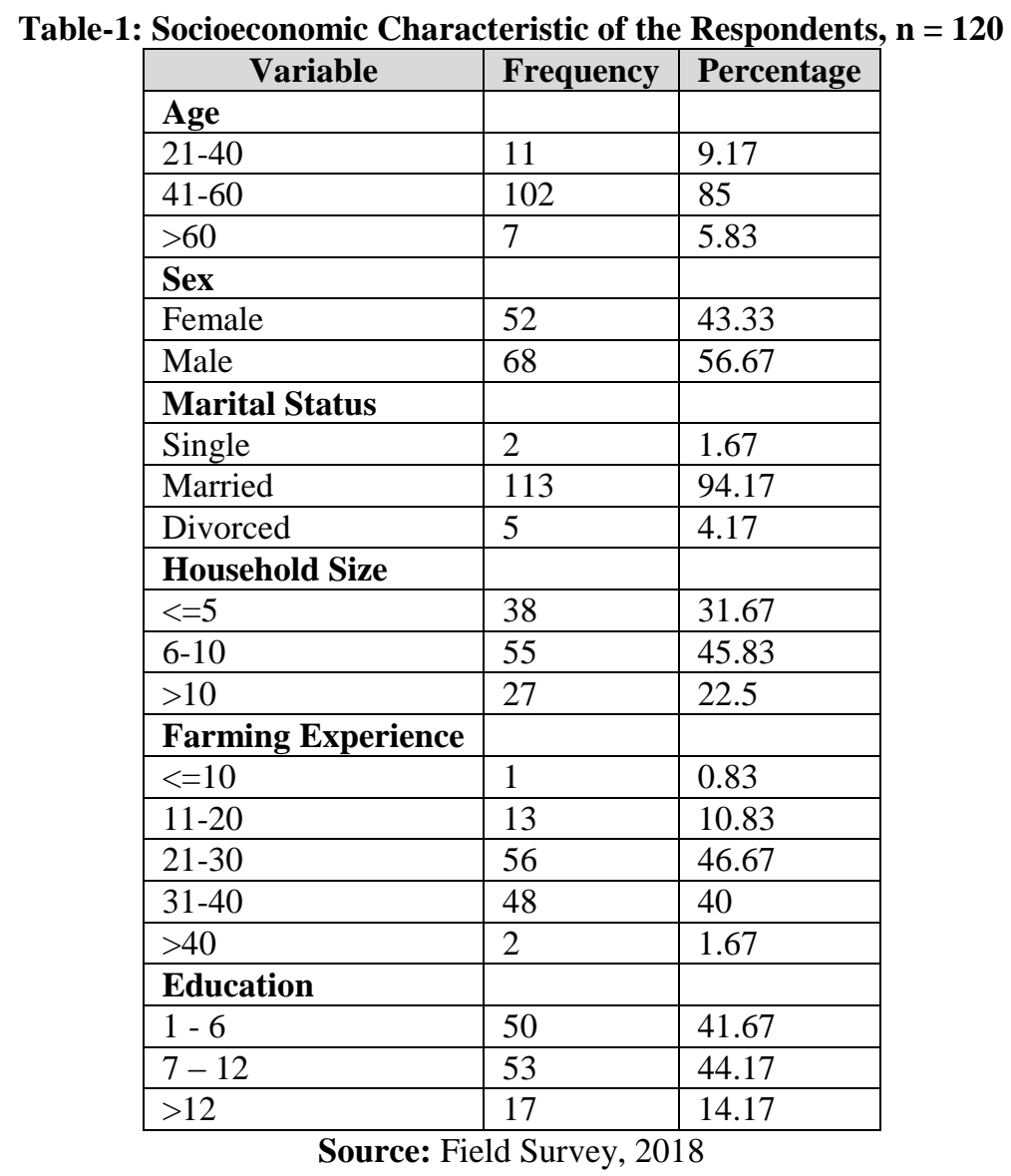

\section{Food Security Status of the Respondents}

The results of the food security status as stated in Table 2 revealed that majority $58.33 \%$ of the respondents were food security while others $(41.67 \%)$ were not secured.

Table-2: Distribution of the Respondents according to Food security Status

\begin{tabular}{|l|l|l|}
\hline Food security status & Frequency & Percentage \\
\hline Non-Food secure & 50 & 41.7 \\
\hline Food secure & 70 & 58.3 \\
\hline Total & 120 & 100.0 \\
\hline
\end{tabular}

Source: Field Survey, 2018

\section{Probit Regression Result: Determinant of Food Security}

The results of the Probit likelihood regression model indicated that the overall predictive power of the model $(34.51 \%)$ is quite high, (Table 3) while the significant Chi square $(\mathrm{p}<0.01)$ is indicative of compatible with access to credit.

As anticipated, farming experience had a positive and significant relationship at $(\mathrm{p}<0.1)$. This implies that the probability of being food secured increases by the number of years of experience in farming of a farmer in the study area as compared with those who have the lower years of experience in farming which are likely to be food insecured. This 
may be due to relatively farmers who have longer years of experience may develop the confidence in handling the risk, skills in technology application. Different studies have agreed with this argument. For instance, Legesse [21], Kidane [22] and Melaku [23] have described the positive relationship of farming experience with food security as perhaps the single most important resource, as it is a base for any economic activity especially in rural and agricultural sector. Farmer's age influences farmers' decision to be more food secured or not. The result further indicated that age of the farmer had influenced on food security significantly and negatively at $(\mathrm{p}<0.05)$. The result in Table 3 also shows that as age of the farmers increased by one unit the probability of being food secured increases but at a decreasing rate (likelihood of being food insecured). This is because the older the farmer becomes the less likelihood he takes risk. A younger farmer who has relatively large size of farmland will not hesitate to try new ways of doing agricultural activities. This will motivate ones innovativeness. The result of the study also revealed that gender of the farmer (sex) increases the probability of being food secured and this implies that male farmers are likely able to be more food secured than their female counterpart. Education was found to influence farmer's ability to be more food secured positively and significantly at $(\mathrm{p}<0.05)$. This result was found to be in conformity to the hypothesis set earlier. In addition, family labour was found to influence food security status household head positively and significantly at $(\mathrm{p}<0.05)$ and reduce the probability of being food insecure. Moreover, hired labour was found to influence the food security status of the household head negatively and significantly at $(\mathrm{p}<0.05)$.

Table-3: Determinant of Food Security

\begin{tabular}{|l|l|l|l|l|l|}
\hline Food Security & Coefficients & Std. Err. & $\mathbf{z}$ & P-value & Mfx \\
\hline Age & -0.96989 & 0.488061 & $-1.99 * *$ & 0.047 & 0.045 \\
\hline Age2 & 0.009238 & 0.004742 & 1.95 & 0.051 & 0.049 \\
\hline Sex & 3.064874 & 0.769514 & 3.98 & 0.000 & 0.000 \\
\hline Primary occupation & -0.14702 & 0.668704 & -0.22 & 0.826 & 0.826 \\
\hline Education & 0.060893 & 0.076054 & $0.8 * *$ & 0.023 & 0.020 \\
\hline Household size & -0.29251 & 0.383935 & -0.76 & 0.446 & 0.439 \\
\hline Extension visit & -1.10528 & 0.984409 & -1.12 & 0.262 & 0.241 \\
\hline Number of family labour & 0.180564 & 0.087887 & $2.05 * *$ & 0.004 & 0.045 \\
\hline Number of hired labour & -0.26513 & 0.135201 & $-1.96 * *$ & 0.005 & 0.031 \\
\hline Constant & 25.61079 & 12.26592 & 2.09 & 0.037 & \\
\hline Number of Observation & 118 & & & \\
\hline LR ${ }^{2}(10)$ & 51.18 & & & & \\
\hline Prob> chi ${ }^{2}$ & 0.000 & & & & \\
\hline Pseudo R ${ }^{2}$ & 0.3451 & & & \\
\hline \multicolumn{7}{|l|}{ Source: Field Survey, 2018 } \\
\hline \multicolumn{7}{|l|}{ Mfx = Marginal Effect } \\
\hline
\end{tabular}

\section{Conclusion}

This study concluded that since farming experience, age of the farmers and family labour was found to influence food security status of household head positively and significantly at farmers should engage more of the service of hired labour according to the size of the farm and in addition, Farmers should form cooperative society in order to boost their finance while government should subsidized input for the farmers

\section{REFERENCES}

1. Drammeh, W. Hamid, N. A., \& Rohana, A.J. (2019). Determinants of Household Food Insecurity and Its Association with Child Malnutrition in Sub-Saharan Africa: A Review of the Literature. Current Research in Nutrition and Food Science, Vol. 07, No. (3) 2019, Pg. 610-623

2. Maharjan, K.L. \& Chhetri, A.K. (2006). Household food security in rural areas of Nepal, Relationship between socio-economic characteristics and food security status. Paper Presented at the International Association of Agricultural Economists' Conference, Gold Coast, Australia, August, 12-26.

3. Barret, C B. (2002). Food security and Food Assistance Programme. Handbook of Agricultural Economics, 2(4): 221.

4. Agidew, Alem-meta Assefa and Singh, K. N. (2018). Determinants of food Insecurity in the rural farm households in South Wollo Zone of Ethiopia: The case of the Teleyayen Subwatershed, Agricultural and Food Economics, 6(10)

5. Nord, M., Andrews, M., Carlson, S. (2008). Household Food Security in the United States, 2007. USDA ERR-66.

6. Cruz, L. (2010). Responsible governance of land tenure: An essential factor for the realization of the right to food. Land Tenure Working Group Discussion Paper 15, FAO. Rome. 
7. Wolfe, W.S., Frongillo, E.A. (2001). Building household food-security measurement tools from the ground up. Food Nutr. Bull. 22:5-12.

8. Coates, J., Swindale, A., Bilinksy, P. (2006). Household food insecurity access scale (HFIAS) for measurement of food access: indicator guide, version 2. Washington, DC: Food and Nutrition Technical Assistance/Academy for Educational Development.

9. Sanusi, R.A., Adebukola, B.C., \& Oyindamola, Y.B. (2006). Measuring household food insecurity in selected local government areas of Lagos and Ibadan, Nigeria. Pak. J. Nutr., 5: 62-67.

10. Abdullateef, U., \& Ijaiya, A. (2010). Agricultural trade liberalization and food security in Nigeria. J. Econ. Int. Finance, 2: 299-307.

11. Okwu, G.N., Ukoha, A.I., Nwachukwu, .N. and Agha, N.C. (2008). Studies on the predisposing factors of protein energy malnutrition among pregnant women in a Nigerian Community. Online J. Health Allied Sci, 6: 1-10.

12. Oluwatayo, I.B. (2008). Explaining inequality and welfare status of households in rural Nigeria: Evidence from Ekiti State. Hum. Soc. Sci. J., 3: 70- 80.

13. IFPRI. (2005). Reaching Sustainable Food Security for All by2020: Getting the Priorities and Responsibilities Right. International Food Policy Research Institute (IFPRI), 1-8.

14. Agboola, P.O., Ikpi A. E Kormawa, P.M. (2004). Factors Influencing Food Insecurity among Rural Farming Households in Africa: Results of Analysis from Nigeria. Internet Discussion Paper, November, 2004. From <http/ www.pjbs.org/pjnonline/ab577.2. (Retrieved on October 2009).

15. Oji-Okoro, I. (2011). "Analysis of the contribution of agricultural sector on the Nigerian economic development." world review of business research, 1(1), $191-200$.

16. Otunaiya, A.O., \& Ibidunni, O.S. (2014). Determinants of Food Security among Rural Farming Households in Ogun State, Nigeria. Journal of sustainable development in Africa, 16(6) 33-45.

17. Matsane, S. H., \& Oyekale, A. S. (2014). Factors affecting marketing of vegetables among small-scale farmers in Mahikeng Local Municipality, North West Province, South Africa. Mediterranean Journal of Social Sciences, 5(20), 390.

18. Oladiran, J. O., LT, O., \& Fanifosi, G. E. (2020). Factors Influencing Market Participation among Food Crop farmers in Oyo State: A Double Hurdle Approach.

19. Global Hunger Index Report. (2012). The Challenge of Hunger: Ensuring Sustainable Food Security under Land, Water and Energy stresses. IFPRI, Concern Worldwide, Welthungerhilfe and Green Scenery: Bonn/ Washington, DC/Dublin October, 2-7.

20. Rios, E. D. C. (2009). Compendium of Brazilian sea shells. Editora Evangraf.

21. Legesse, N., \& Powell, A. A. (1992). Comparisons of water uptake and imbibition damage in eleven cowpea cultivars. Seed Science and Technology, 20(1), 173-180.

22. Kidane, A., Guimond, P., Ju, T. C. R., Sanchez, M., Gibson, J., \& Bowersock, T. L. (2001). The efficacy of oral vaccination of mice with alginate encapsulated outer membrane proteins of Pasteurella haemolytica and OneShot®. Vaccine, 19(17-19), 2637-2646.

23. Melaku, S., Dams, R., \& Moens, L. (2005). Determination of trace elements in agricultural soil samples by inductively coupled plasma-mass spectrometry: microwave acid digestion versus aqua regia extraction. Analytica Chimica Acta, 543(1-2), 117-123.

24. Ijarotimi, O.S., \& Oyeneyin O.O. (2005). Effects of Economy Restructuring on Household Food Security and Nutrition Status of Nigeria Children. Journal of Food Agriculture and Environment.

Citation: Adio Matthew Olufemi \& Oladele, Adeniyi Bamidele (2021). Food Insecurity and its Determinants among Farming Households in Surulere Local Government Area of Oyo State. South Asian Res J Agri Fish, 3(2), 10-16. 